\title{
New Distributional Records of Lichens for the State of Mizoram, Indo-Burma Region of India
}

\author{
Nurpen Meitei Thangjam¹, Awadhesh Kumar ${ }^{1, *}$, \\ Tbc Laldingliani ${ }^{1}$ and Dalip Kumar Upreti $^{2}$
}

\author{
${ }^{1}$ Department of Horticulture Aromatic \& Medicinal Plants, School of Earth Sciences \& Natural Resource \\ Management, Mizoram University, Aizawl 796009, Mizoram, India \\ ${ }^{2}$ Lichenology Laboratory, Plant Diversity Systematics and Herbarium Division, CSIR-National Botanical \\ Research Institute, Rana Pratap Marg, Lucknow 226001, Uttar Pradesh, India
}

('Corresponding author's e-mail: kumarawadhesh9@gmail.com)

Received: 21 September 2020, Revised: 21 May 2021, Accepted: 21 June 2021

\begin{abstract}
The present paper enumerated the occurrence of 30 different species of lichens collected from 2 different study sites situated in 2 districts of Mizoram. It included Crustose (12 sp.), Foliose (16 sp.) and Fruticose (2 sp.) along with 9 species named as Diploschistes scruposus (Schreb.) Norman, Diorygma macgregorii (Vain.) Kalb, Staiger \& Elix, Diorygma soozanum (Zahlbr.) M. Nakan. \& Kashiw., Malmidea granifera (Ach.) Kalb, Rivas Plata \& Lumbsch, Letrouitia vulpina (Tuck.) Hafellner \& Bellem., Parmotrema austrosinense (Zahlbr.) Hale, Parmotrema crinitoides J.C. Wei, Parmotrema nilgherrense (Nyl.) Hale, Parmotrema rampoddense (Nyl.) Hale reported as a new record for the $1^{\text {st }}$ time to the state of Mizoram, Northeast India. The finding were correlated with other previous reports on lichens and it provided detailed overview of documentation, distribution and diversity of lichens found in the small state like Mizoram under Indo-Burma region. Therefore, the richness of lichen diversity indicates the conditions of good forest health in Mizoram. The study also submits the need of conservation and exploration in the unexplored areas.
\end{abstract}

Keywords: Documentation, Indo-Burma region, Lichens diversity, Mizoram, New records

\section{Introduction}

Lichens comes under the category of lower plants, a composite organisms, comprises of dominant fungal partner (mycobiont) and one or more photosynthetic partners (photobiont) in a symbiotic relationship. The lichens are dominated by mycobiont and occasionally categorized as a life dependent of fungi [1,2]. For the lichens group there is no proper natural system of classification; they usually classify on the nature and kinds of fruiting bodies of the fungal partner, and it is integrate in the system of fungi [3]. Lichens are the perennial plants which are very slow in growth specially the mycobiont. Both partners have the very distinct role in the lichens life like photobiont produced the food through process of photosynthesis and supplied to the whole body; whereas mycobiont utilized the food and helps in reproduction [4].

Lichens are widely distributed in all the geographical region of the world. The total numbers of lichens species as well as lichenized fungi are estimated about 17,000 to 20,000 species around the world [5]. However, Aptroot reported that the biodiversity of fungi is very high but the number of projected species is varies and it was estimated 30,000 as a recognized species with known ascomycetes [6]. But, according to latest updates of lichens species, it was reported that number of accepted species is 19,387 in 995 genera and 115 families with family Parmeliaceae is the highest number of species with 2,765 spp. and 77 genera followed by Graphidaceae with 2,161 spp. and 79 genera [7].

Globally, India was counted as the $5^{\text {th }}$ nation around the world for its biodiversity and overall 2,303 lichen species were recorded under 305 genera and 74 families. The foliose lichens of family Parmeliaceae are dominant in the diversity with $345 \mathrm{spp}$. and they are widely distributed in subtropical, temperate and alpine regions of India; crustose lichens of family Graphidaceae with 278 spp. distributed in tropical and subtropical regions followed by the families Thelotremataceae, Pyrenulaceae, Caliciaceae, Lecanoraceae, Physciaceae, Tryptheliaceae, Teloschistaceae and Collemataceae [8]. Moreover, Singh et 
al. reported the addition of 411 species to the list of annotated checklist 2010, therefore the total number of lichens recorded from India became 2,714 [9].

The Indian geography mainly consists of 4 biodiversity hot spot where entire North Eastern Region (NER) comprised of 8 states (Assam, Arunachal Pradesh, Meghalaya, Manipur, Mizoram, Nagaland, Sikkim and Tripura) was included in Indo-Burma region. The region is rich in varieties of living organism with huge variation in flora and fauna having maximum area under forest cover; and the nature has also provided the diverse vegetation of all the group of plants $[10,11]$. Therefore, it has been always bird's eye view for researcher to explore and investigate new species from this region. With concern to lichens, so far, the NER were recorded with $41.22 \%$ (1,047 species) of the total lichen diversity of the country and the growth forms of lichens distribution were recorded as 592 in crustose, 321 foliose, 125 fruticose and 9 squamulose under 212 genera and 63 families [9]. Since the report of lichens diversity in NER is still unexplored in different remote areas and many species are remain unidentified as far as the literature and the studies were concerned [12]. Moreover, Lichens as whole and its identified metabolites have reported for numerous biological activities including antimicrobial, antiprotozoal, antiviral, antiproliferative, antiinflammatory, analgesic, antipyretic, antitermite, antioxidant, cytotoxic, enzyme inhibitory, insecticidal, wound healing, antitumor as well as enzyme inhibitory [13-15].

As per annotated check list made by Singh and Sinha [8] the 2 lichens species such as Cladonia fruticulosa Kremp. and Cladonia submultiformis Asahina only a report from Mizoram. Further, 169 species of lichens with 14 species as the new record in the lichens biota of India were reported from Mizoram state, and once again it was seen that the family Parmeliaceae as dominated the distribution of lichens in the state [16]. Despite of rich in diversity, the exploration of lichens in the different areas were still unexplored in the state, therefore the present studies were carried out in 2 selected sites viz. Reiek hill, (one of the tourist spot in Mamit District) and Mizoram University campus (MZU) (Aizawl District) and both places are known for more variations in their ecology and environment.

\section{Study sites}

Mizoram is the state belongs in the NER of India. The maximum part of state is covered by forest according to their forest report of 2015 [17]. The topography of the region consists of parallel hill ranges running in north-south direction in the altitude vary from 40 to $2,157 \mathrm{~m}$. The state has a total forest area of 18,576 sq km. Forest cover is primary and secondary type comprising tropical wet evergreen, tropical semi-evergreen and sub-tropical type forests. The climatic condition and the forest types both provide a suitable condition for growth of many plant groups from lower to higher including lichens [18].

\section{Reiek hill}

Reiek hill is located in the Mamit District of Mizoram with distance of $29 \mathrm{~km}$ from the main capital city of Aizawl. It lies between $20^{\circ} 45^{\prime}$ and $22^{\circ} 28^{\prime} \mathrm{N}$ latitude and $92^{\circ} 37^{\prime}$ and $93^{\circ} 46^{\prime}$ E longitude with the altitude of 1,465 m. Since, 1980s the Chief of Sailo's was declared Reiek forest as a protected area and to maintain and conserve the biodiversity. The forest has a pleasant climatic condition having chilled winters and mild summer with heavy rainfall where the temperature ranges from $6-22{ }^{\circ} \mathrm{C}$ and $20-28{ }^{\circ} \mathrm{C}$ in winter and summer respectively. The whole forest is covered with rocky-sandy soil in the top layer, hard stone plates in the peak and the rest parts with sandy-loam to black humus. The vegetation of the forest is tropical semi-evergreen forest or subtropical evergreen forest $[19,20]$.

It is a mountain and one of the most peaceful and breathtaking tourist spot of Mizoram. Reiek hill was surrounded by the thick lush green temperate trees and bushes and the plain region of the Bangladesh can be seen clearly from the hill top on the fine sunny day. This area is also the venue for the annually conducted festival called "Anthurium" for the promotion of tribal art and cultures including plantation and conservation strategies of forest [21].

\section{Mizoram University campus}

MZU is located nearby Tanhril village in the western part and $15 \mathrm{~km}$ away from the Aizawl city. It lies between $23^{\circ} 45^{\prime} 25^{\prime \prime}$ and $23^{\circ} 43^{\prime} 37^{\prime \prime} \mathrm{N}$ latitude and $92^{\circ} 38^{\prime} 39^{\prime \prime}$ and $92^{\circ} 40^{\prime} 23^{\prime \prime} \mathrm{E}$ and covered the areas of 978.1988 acres with altitude ranging from 300 to $880 \mathrm{~m}$ above sea level. The climatic condition is humid with winter (November - February), summer (March - October) with adequate rainfall and the temperature ranges from $13-36^{\circ} \mathrm{C}$ throughout the year [22].

The entire area was covered with a dense forest and full of different vegetation till 1960; later it was deforested and used for agriculture, because agriculture was the main occupation of the peoples during those days; thus, the vegetation of the campus also falls under tropical semi-evergreen forest. Plant diversity in this area is quite rich particularly in the western sides representing the forest with less biotic 
disturbance. MZU campus now having its own boundary since 2001, that is why it is highly diverse in natural habitat and ecosystem [23].

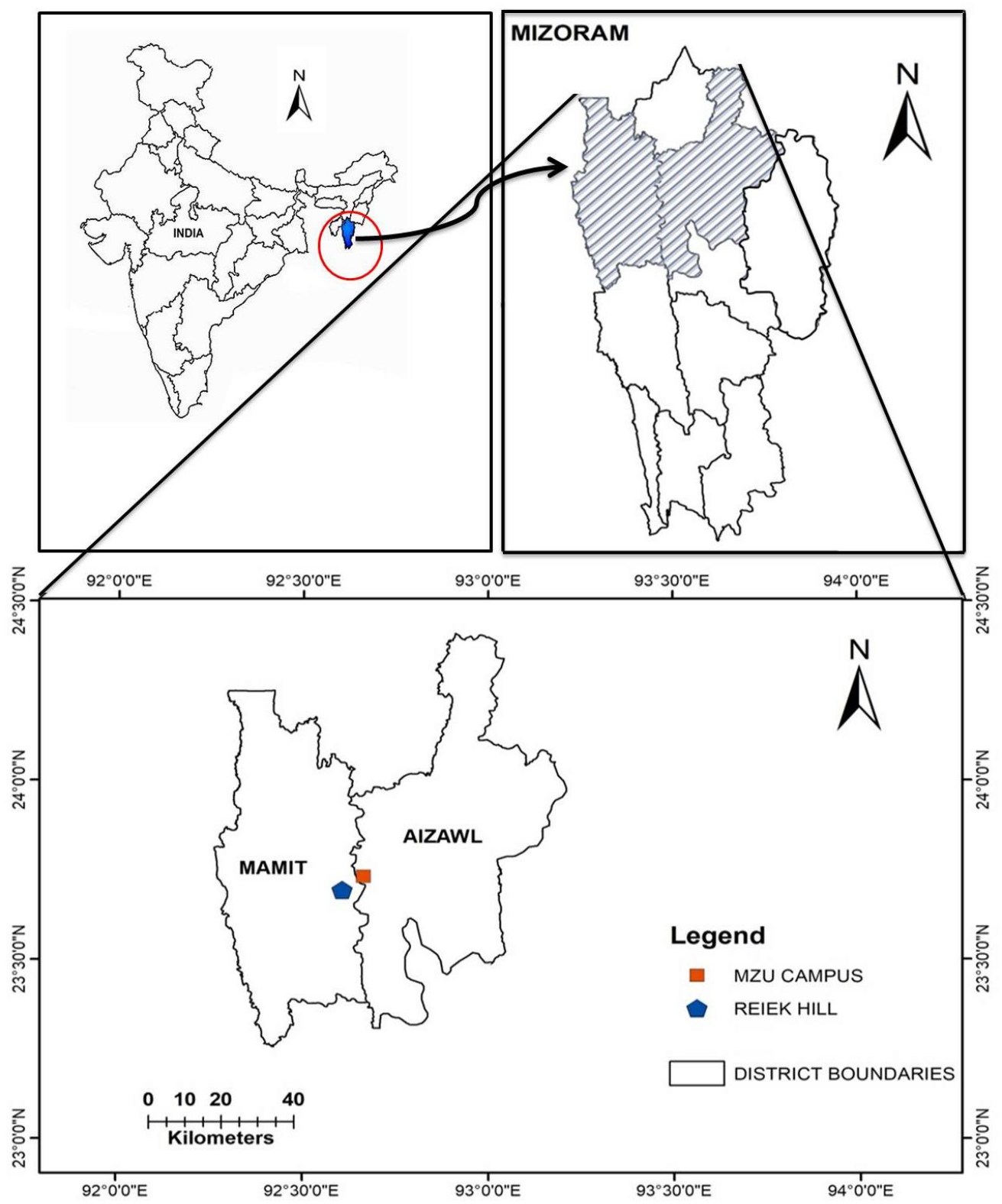

Figure 1 GIS Mapping of 2 study sites MZU campus and Reiek hill.

\section{Materials and methods}

\section{Collection and categorization of lichens}

A frequent field visit was conducted from December, 2018 to October, 2019 in all the selected sites for collection of lichen specimens. The methods of collection were made on simple floristic study, the lichens was collected with substratum based on their growth form by using a sharp, flat edged chisel (1 to 2 inch) and a hammer ( 1 to $2 \mathrm{~kg}$ weight) with a hand lens of $10 \times$ zoom to examine the structure of the thallus. The collected lichen samples were packed in polythene bag and tight with rubber bands with proper labeling [24,25]. Further, the processing of specimens like removal of unwanted materials (bryophytes and substratum) as well as drying process by using hot air oven was carried out in Department of Horticulture, Aromatic and Medicinal Plants (HAMP), MZU, Aizawl; and finally 
preserved for herbarium. Based on growth forms of lichen (crustose, foliose and fruticose) the categorization process was made. The lichens having ethnomedicinal importance were emphasized for detail studies during the research work.

\section{Identification of lichens}

The lichens specimens were identified through comparative studies based on their anatomical, morphological and biochemical observations and it was done at Lichenology Laboratory, CSIR-National Botanical Research Institute (NBRI), Lucknow. The morphological variations of each specimen were studied by using Leica S8APO stereo-zoom microscope, whereas anatomical studies were made by Leica DM500 compound microscope. The microscopic details of each specimen were performed by cutting the transverse section of fruiting bodies, where the cotton blue was used as a staining media and lactophenol as mounting media [2]. Moreover, the specimens were identified and authenticated with previous literatures on lichens [26-30].

Thin layer chromatography (TLC) was also conducted for the identification. It was mainly performed in solvent system A (Toluene: 1, 4-dioxane: acetic acid: 180: 60: $8 \mathrm{~mL}$ ) but sometimes in solvent system B (Hexane: Diethyl ether: Formic acid: 130: 100: $20 \mathrm{~mL}$ ). The chemical substances were extracted in acetone and loaded on silica gel pre-coated aluminium plates. After running in solvent system A, the TLC plates were sprayed with distilled water for checking the presence of fatty acids. Later the plates were sprayed with $10 \% \mathrm{H}_{2} \mathrm{SO}_{4}$ solution and heated in hot air oven at $110-120{ }^{\circ} \mathrm{C}$ till the color spots develops, due to charring. Parmelinella wallichiana (Taylor) Elix and Hale, having Salazinic acid (Rf class 2), Norstictic acid (Rf class 4) and Atranorin (Rf class 7) were used as reference material. The TLC was observed under UV radiations at $350 \mathrm{~nm}$ wavelength before and after charring [24,31,32].

\section{Documentation of lichens (Herbarium Database)}

Based on the above morphological and chemical characterizations; the identified lichens were confirmed with the help of Lichenologist in the Laboratory of Lichenology, National Botanical Research Institute (CSIR Lab) and the identified lichens specimens were properly packed inside a herbarium packet which is specifically made for Lichens. The herbarium sheets were categorized with area of collection, date of collection, name of lichens and its family, altitude and name of collector. Lastly, all the specimens were deposited in lichen herbarium (LWG) of CSIR-NBRI, Lucknow as well as Department of HAMP, MZU, Aizawl.

\section{Results and discussion}

From the 2 selected sites, 20 different species of lichens belonging to 11 genera and 8 families reported from $1^{\text {st }}$ site i.e., Reiek hill, Mamit District of Mizoram state.

Out of 2 selected sites, the $1^{\text {st }}$ site - Reiek hill, Mamit District of Mizoram state has reported for 20 different species of lichens belonging to 11 genera and 8 families. The family Parmeliaceae possessed highest number of species (9 sp.) among the distribution of families, followed by Graphidaceae (4 sp.), Pyrenulaceae (2 sp.). The families like Coccocarpiaceae, Letrouitiaceae, Pertusariaceae, Physciaceae and Roccellaceae were also contributed $1 \mathrm{sp}$. in each family. While the $2^{\text {nd }}$ site - MZU campus all together 16 different species of lichens belonging to 8 genera and 6 families were reported. This site also showed the family Parmeliaceae with highest number of lichens species (6 sp.) among the reported families. Further, it was followed by family Physciaceae (4 sp.), Caliciaceae and Graphidaceae ( $2 \mathrm{sp}$. in each), whereas, family Malmideaceae and Pertusariaceae with $1 \mathrm{sp}$. were stands on lowest number shown in Table 1 and Figure 4.

The present study was encouraged by similar studies conducted in the Eastern Himalayan region by various lichenologists where they found the enormous growth of lichens diversity. Daimari et al. [33] documented the distribution of epiphytic lichens from 3 different districts like Baksa, Kamrup and Sonitpur of Assam and reported 67 species under 12 families and 24 genera along with 41 lichen species as new records for the state of Assam. It also showed that family Physciaceae dominated with 20 species followed by Graphidaceae with 16 species. Recently, Gogoi et al. added 25 new records of lichens under 19 genera and 11 families for the state of Assam [34]. Similarly, Debnath et al. added 17 new species collected from West Kameng district and Tawang district which is located in the Eastern Himalayas of Arunachal Pradesh [35]. Whereas, Devi et al. also reported a total of 39 lichen species as new records for the state of Manipur, Northeast India and 14 species as an addition for the North East lichens biota from the total of 140 species under 50 genera and 23 families [25]. Further, Singh and Singh have shown the $1^{\text {st }}$ 
report from Meghalaya on distribution of lichens with 39 species including Porina eminentior as a new record for India [36].

Table 1 Lichen flora documented from Reiek hill, Mamit District and MZU campus, Aizawl district, Mizoram.

\begin{tabular}{|c|c|c|c|c|c|c|}
\hline $\begin{array}{l}\text { SI. } \\
\text { no. }\end{array}$ & Family & Genus & Species & Field No. & $\begin{array}{l}\text { Collected } \\
\text { area }\end{array}$ & $\begin{array}{l}\text { Growth } \\
\text { form }\end{array}$ \\
\hline 1 & Coccocarpiaceae & Coccocarpia & $\begin{array}{c}\text { Coccocarpia palmicola (Spreng.) Arv. } \\
\text { \& D.J. Galloway }\end{array}$ & $18-036149$ & Reiek & Foliose \\
\hline 2 & Caliciaceae & Dirinaria & $\begin{array}{c}\text { Dirinaria aegialita (Afzel. ex Ach.) } \\
\text { B.J. Moore }\end{array}$ & $18-036166$ & MZU & Foliose \\
\hline 3 & Caliciaceae & Dirinaria & $\begin{array}{c}\text { Dirinaria consimilis (Stirt.) D.D. } \\
\text { Awasthi }\end{array}$ & $18-036167$ & MZU & Crustose \\
\hline 4 & Graphidaceae & Diploschistes & $\begin{array}{c}\text { Diploschistes scruposus (Schreb.) } \\
\text { Norman }\end{array}$ & $18-036148$ & Reiek & Crustose \\
\hline 5 & Graphidaceae & Diorygma & $\begin{array}{l}\text { Diorygma hieroglyphicum (Pers.) } \\
\text { Staiger \& Kalb }\end{array}$ & $18-036136$ & Reiek & Crustose \\
\hline 6 & Graphidaceae & Diorygma & $\begin{array}{c}\text { Diorygma junghuhnii (Mont. \& Bosch) } \\
\text { Kalb, Staiger \& Elix }\end{array}$ & $18-036131$ & MZU & Crustose \\
\hline 7 & Graphidaceae & Diorygma & $\begin{array}{c}\text { Diorygma macgregorii (Vain.) Kalb, } \\
\text { Staiger \& Elix }\end{array}$ & $18-036133$ & Reiek & Crustose \\
\hline 8 & Graphidaceae & Diorygma & $\begin{array}{c}\text { Diorygma soozanum (Zahlbr.) M. } \\
\text { Nakan. \& Kashiw. }\end{array}$ & $\begin{array}{l}18-036137 \\
18-036134\end{array}$ & $\begin{array}{l}\text { Reiek, } \\
\text { MZU }\end{array}$ & Crustose \\
\hline 9 & Malmideaceae & Malmidea & $\begin{array}{c}\text { Malmidea granifera (Ach.) Kalb, Rivas } \\
\text { Plata \& Lumbsch }\end{array}$ & $18-036168$ & MZU & Crustose \\
\hline 10 & Letrouitiaceae & Letrouitia & $\begin{array}{c}\text { Letrouitia vulpine (Tuck.) Hafellner \& } \\
\text { Bellem. }\end{array}$ & $18-036151$ & Reiek & Crustose \\
\hline 11 & Parmeliaceae & Bulbothrix & Bulbothrix isidiza (Nyl.) Hale & $18-036159$ & MZU & Foliose \\
\hline 12 & Parmeliaceae & Parmotrema & $\begin{array}{c}\text { Parmotrema austrosinense (Zahlbr.) } \\
\text { Hale }\end{array}$ & $18-036158$ & MZU & Foliose \\
\hline 13 & Parmeliaceae & Parmotrema & Parmotrema crinitoides J.C. Wei & $18-036135$ & Reiek & Foliose \\
\hline 14 & Parmeliaceae & Parmotrema & $\begin{array}{c}\text { Parmotrema hababianum (Gyeln.) } \\
\text { Hale }\end{array}$ & $18-036146$ & Reiek & Foliose \\
\hline 15 & Parmeliaceae & Parmotrema & Parmotrema nilgherrense (Nyl.) Hale & $18-036138$ & Reiek & Foliose \\
\hline 16 & Parmeliaceae & Parmotrema & $\begin{array}{c}\text { Parmotrema praesorediosum (Nyl.) } \\
\text { Hale }\end{array}$ & $18-036160$ & MZU & Foliose \\
\hline 17 & Parmeliaceae & Parmotrema & Parmotrema rampoddense (Nyl.) Hale & $\begin{array}{l}18-036156 \\
18-036169\end{array}$ & $\begin{array}{l}\text { Reiek, } \\
\text { MZU }\end{array}$ & Foliose \\
\hline 18 & Parmeliaceae & Parmotrema & $\begin{array}{c}\text { Parmotrema reticulatum (Taylor) M. } \\
\text { Choisy }\end{array}$ & $18-036140$ & Reiek & Foliose \\
\hline 19 & Parmeliaceae & Parmotrema & $\begin{array}{c}\text { Parmotrema tinctorum (Despr. ex } \\
\text { Nyl.) Hale }\end{array}$ & $\begin{array}{l}18-036155 \\
18-036170\end{array}$ & $\begin{array}{l}\text { Reiek, } \\
\text { MZU }\end{array}$ & Foliose \\
\hline 20 & Parmeliaceae & $\begin{array}{l}\text { Remototrachy } \\
\text { na }\end{array}$ & $\begin{array}{c}\text { Remototrachyna rhabdiformis (Kurok.) } \\
\text { Divakar \& A. Crespo }\end{array}$ & $18-036139$ & Reiek & Foliose \\
\hline 21 & Parmeliaceae & Usnea & Usnea baileyi (Stirt.) Zahlbr. & $\begin{array}{l}18-036153 \\
18-036171\end{array}$ & $\begin{array}{l}\text { Reiek, } \\
\text { MZU }\end{array}$ & Fruticose \\
\hline 22 & Parmeliaceae & Usnea & Usnea eumitrioides Motyka & $18-036154$ & Reiek & Fruticose \\
\hline 23 & Pertusariaceae & Pertusaria & Pertusaria leucosorodes Nyl. & $\begin{array}{l}18-036147, \\
18-036161\end{array}$ & $\begin{array}{l}\text { Reiek, } \\
\text { MZU }\end{array}$ & Crustose \\
\hline 24 & Physciaceae & Heterodermia & $\begin{array}{c}\text { Heterodermia albidiflava (Kurok.) } \\
\text { D.D. Awasthi }\end{array}$ & $18-036164$ & MZU & Foliose \\
\hline 25 & Physciaceae & Heterodermia & $\begin{array}{l}\text { Heterodermia diademata (Taylor) D.D. } \\
\text { Awasthi }\end{array}$ & $\begin{array}{l}18-036157 \\
18-036163\end{array}$ & $\begin{array}{l}\text { Reiek, } \\
\text { MZU }\end{array}$ & Foliose \\
\hline 26 & Physciaceae & Heterodermia & $\begin{array}{l}\text { Heterodermia hypochraea (Vain.) } \\
\text { Swinscow \& Krog }\end{array}$ & $18-036162$ & MZU & Foliose \\
\hline 27 & Physciaceae & Heterodermia & Heterodermiaobscurata (Nyl.) Trevis. & $18-036165$ & MZU & Foliose \\
\hline
\end{tabular}




\begin{tabular}{ccccccc}
\hline $\begin{array}{c}\text { Sl. } \\
\text { no. }\end{array}$ & Family & Genus & Species & Field No. & $\begin{array}{c}\text { Collected } \\
\text { area }\end{array}$ & $\begin{array}{c}\text { Growth } \\
\text { form }\end{array}$ \\
\hline 28 & Pyrenulaceae & Pyrenula & $\begin{array}{c}\text { Pyrenula mastophoroides (Nyl.) } \\
\text { Zahlbr. }\end{array}$ & $18-036152$ & Reiek & Crustose \\
& & Pyrenula & Pyrenula andinaAptroot & $18-036132$ & Reiek & Crustose \\
29 & Pyrenulaceae & Chiodecton & Chiodecton leptosporum Müll. Arg. & $18-036150$ & Reiek & Crustose \\
\hline
\end{tabular}

In sequence of above all studies, the present study has also recorded 30 species of lichens from the selected sites as shown in Figure 3. Out of which 9 species were recorded as $1^{\text {st }}$ time report for the state of Mizoram. On basis of growth forms, both study sites were dominated by the foliose lichens having 16 species followed by crustose (12 species) and fruticose ( 2 species) respectively. TLC was the very important technique in respect to lichens identification; and it is employed to check the presence of acids in lichens samples. The different colors spots developed through TLC process were the main source for identification as shown in Figure 2.

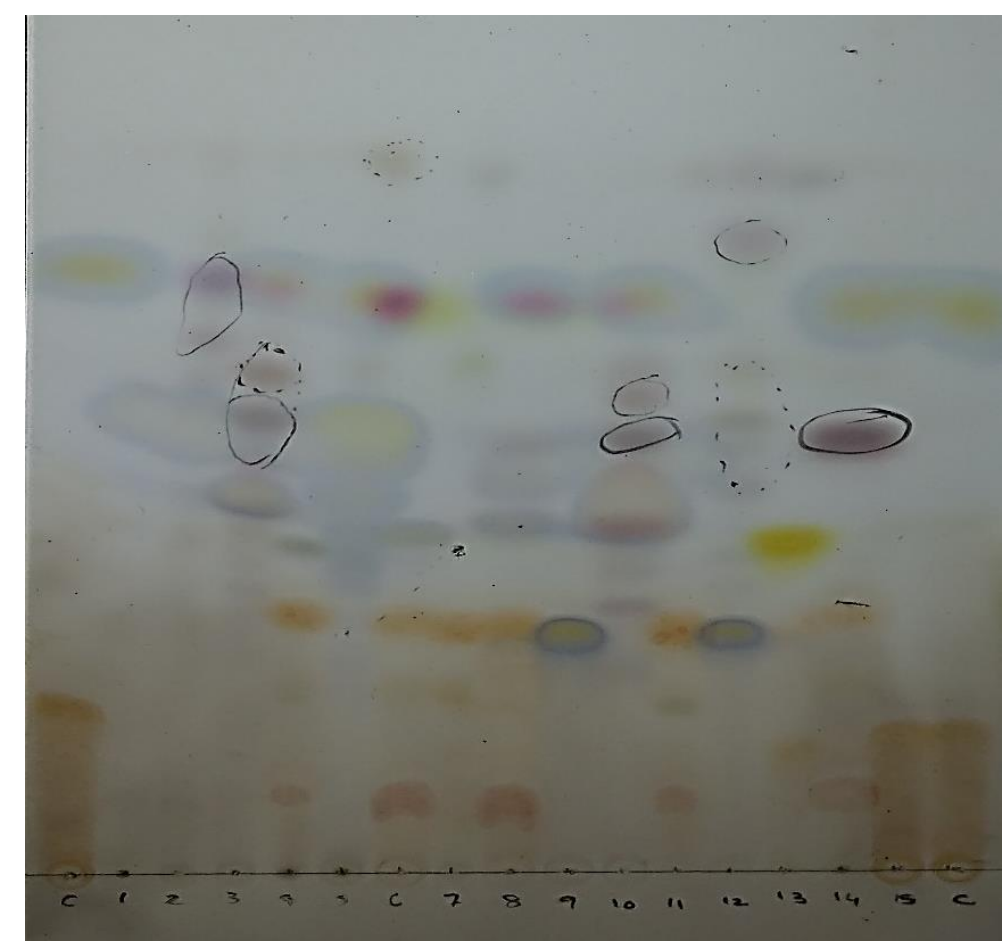

Figure 2 Lichens acid detected in the TLC plate.

The new systematic studies on lichens of Mizoram state truly started with the report of Logesh et al. [16] where he added 159 lichen species as new distributional records from the said state. He contributed total numbers of 14 lichen species as new records for Indian lichen biota. The initial work for above study was provided by Chinlampianga et al. with the report of 10 lichen species and it was the $1^{\text {st }}$ properly published documentation from Aizawl, Mizoram; and it was considered as base line data for the lichens studies from the state [37]. Recently, another finding was reported with 42 lichen species from the IndoBurma hotspot region of Champhai district, Mizoram. In this findings $21 \mathrm{sp}$. were the $1^{\text {st }}$ time reported from the state with addition of Pyrenula dissimulans as a new record to Indian lichen biota [2,38]. 


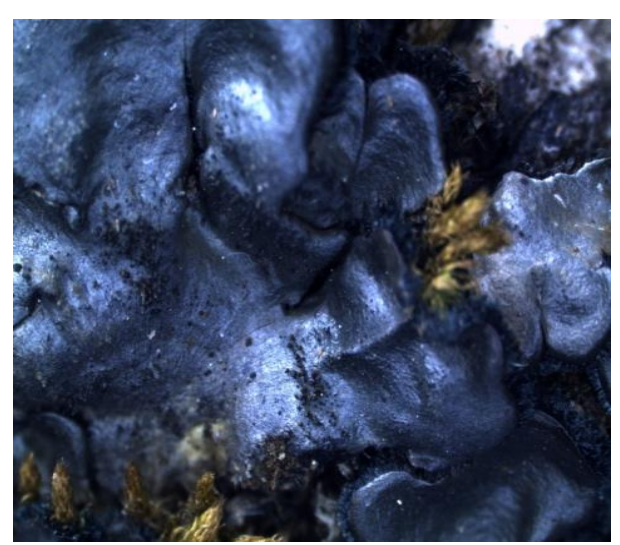

Coccocarpia palmicola (Spreng.) Arv. \& D.J. Galloway

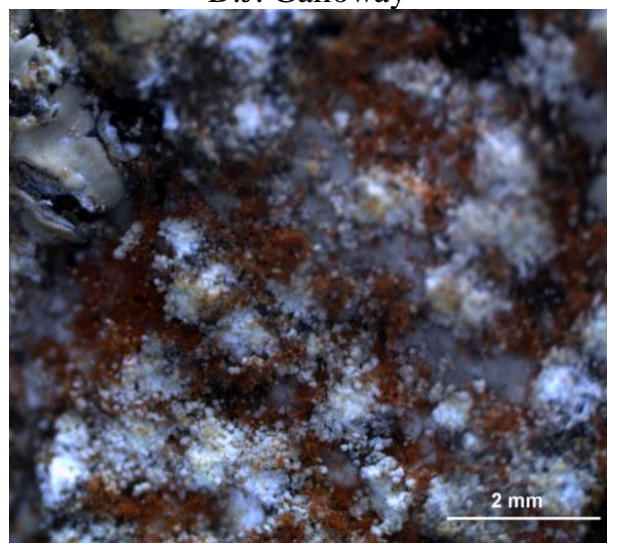

Dirinaria consimilis (Stirt.) D.D. Awasthi

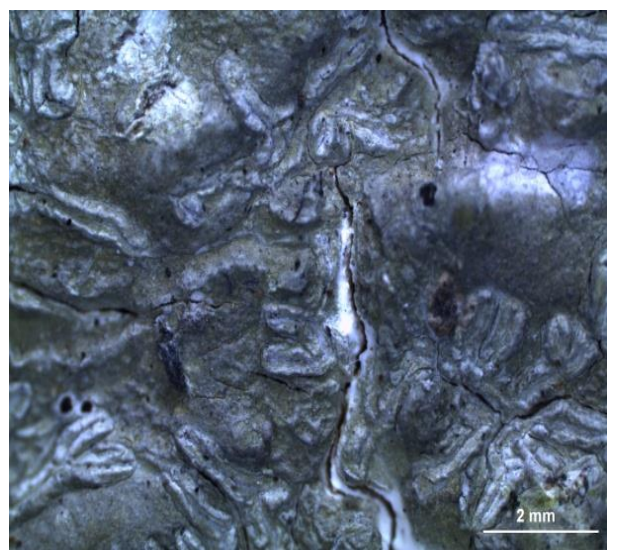

Diorygma hieroglyphicum (Pers.) Staiger \& Kalb

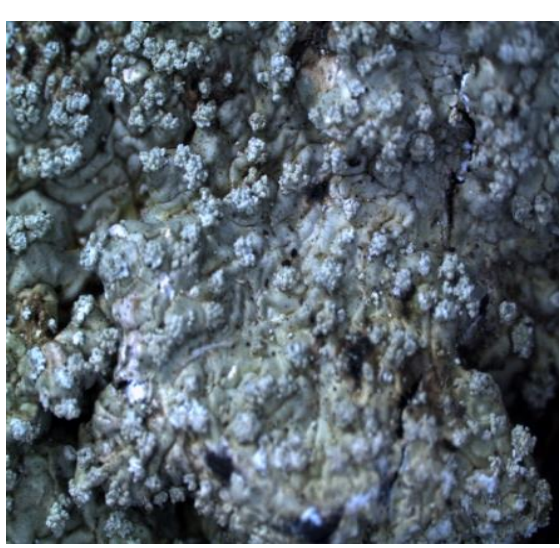

Dirinaria aegialita (Afzel. ex Ach.) B.J. Moore

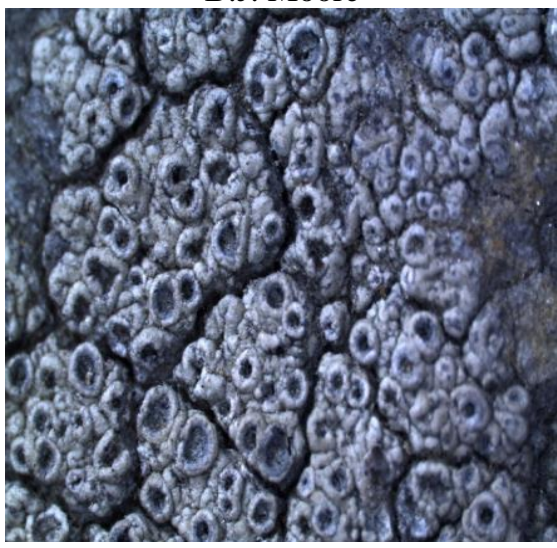

Diploschistes scruposus (Schreb.) Norman

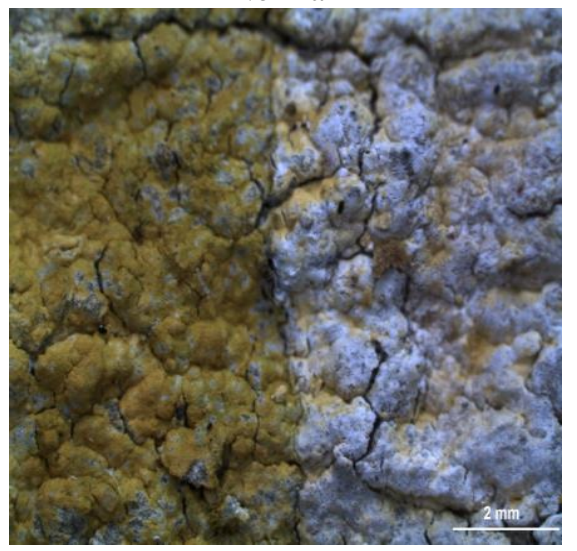

Diorygma junghuhnii (Mont. \& Bosch) Kalb, Staiger \& Elix 


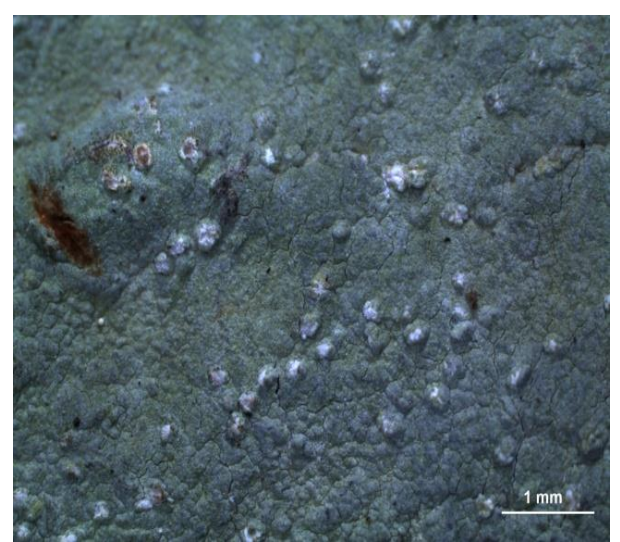

Diorygma macgregorii (Vain.) Kalb, Staiger \& Elix

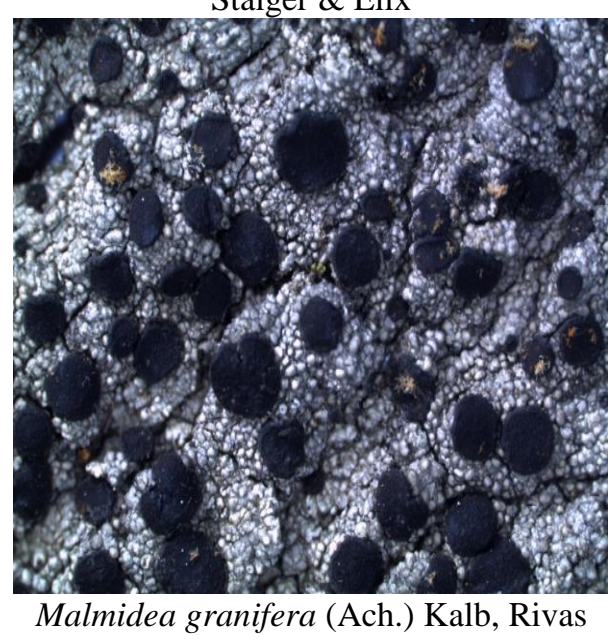

Plata \& Lumbsch

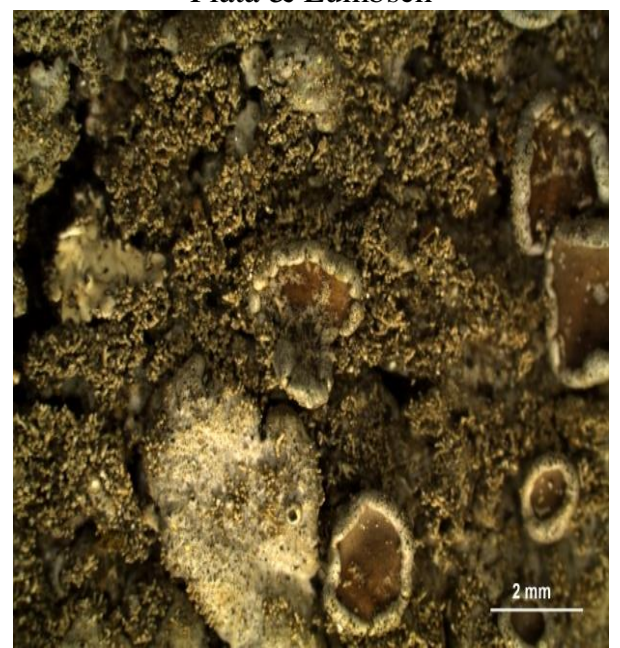

Bulbothrix isidiza (Nyl.) Hale

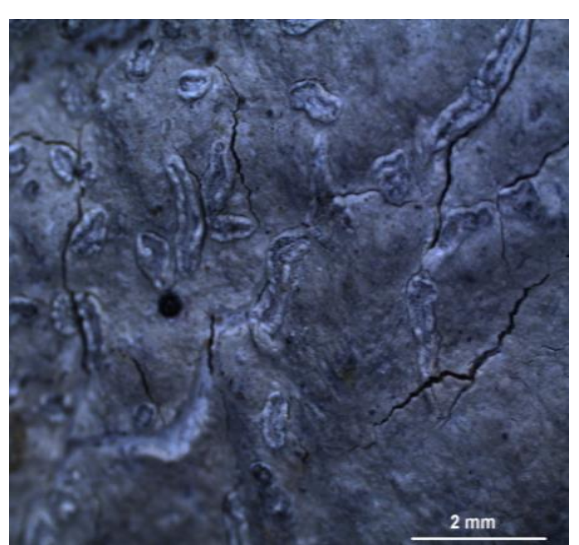

Diorygma soozanum (Zahlbr.) M. Nakan. \& Kashiw.

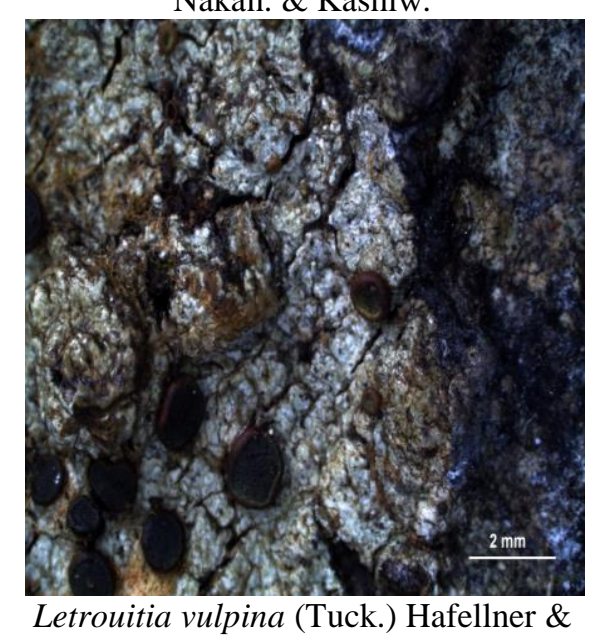
Bellem.

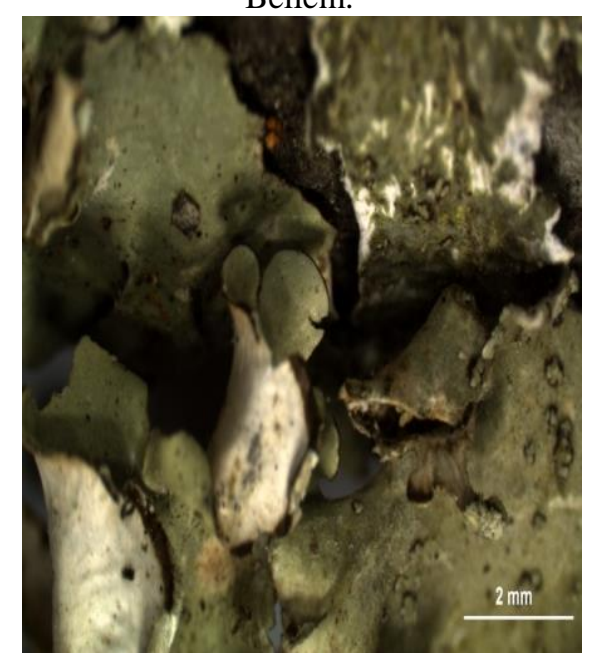

Parmotrema austrosinense (Zahlbr.) Hale 


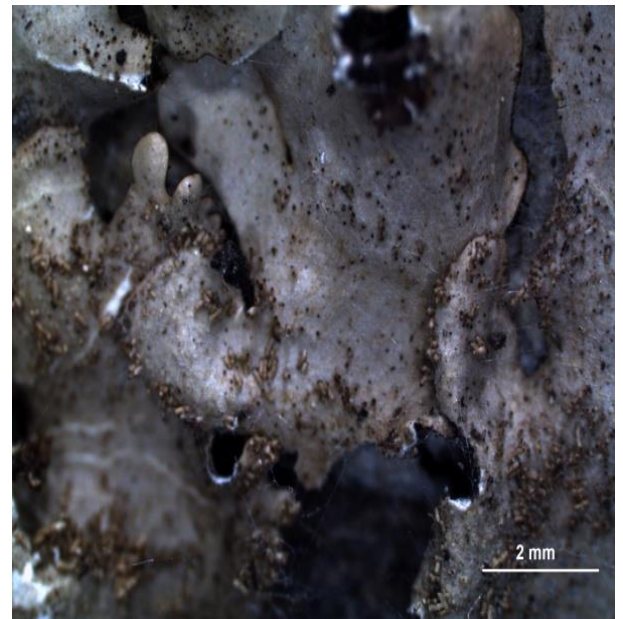

Parmotrema crinitoides J.C. Wei

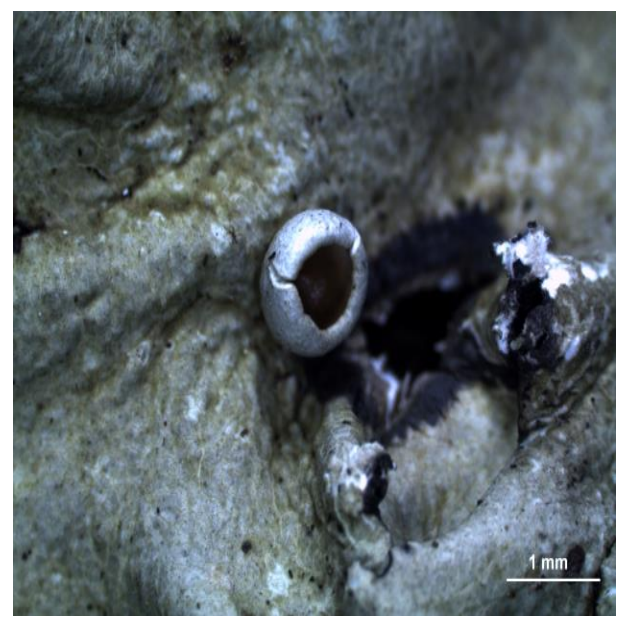

Parmotrema nilgherrense (Nyl.) Hale

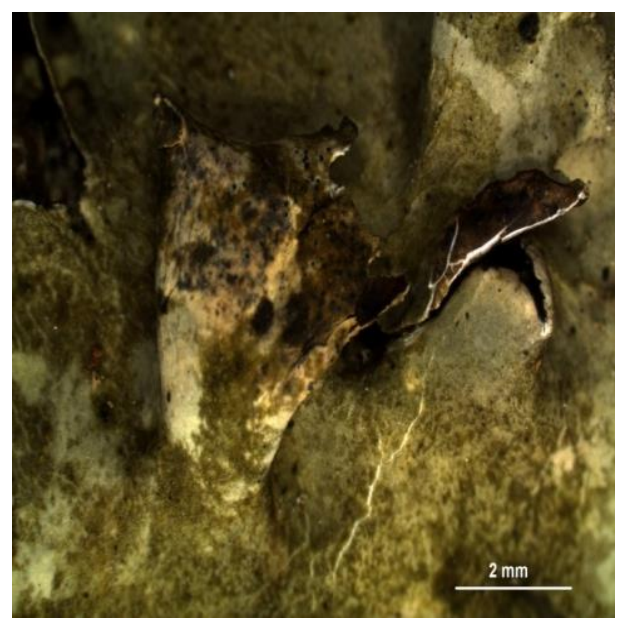

Parmotrema rampoddense (Nyl.) Hale

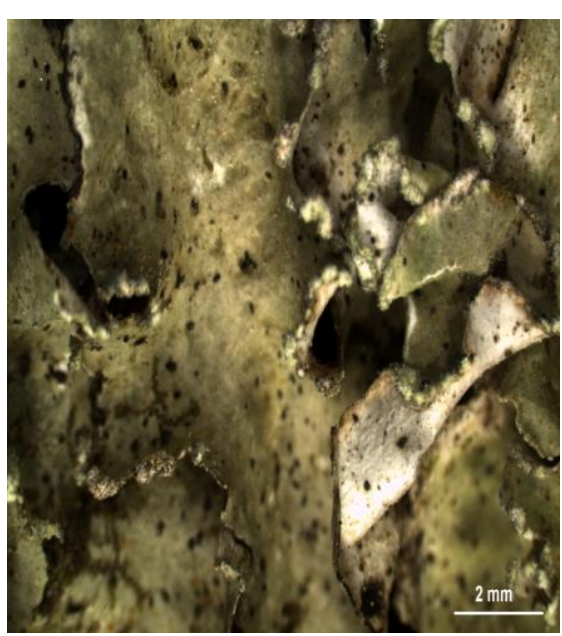

Parmotrema hababianum (Gyeln.)

Hale

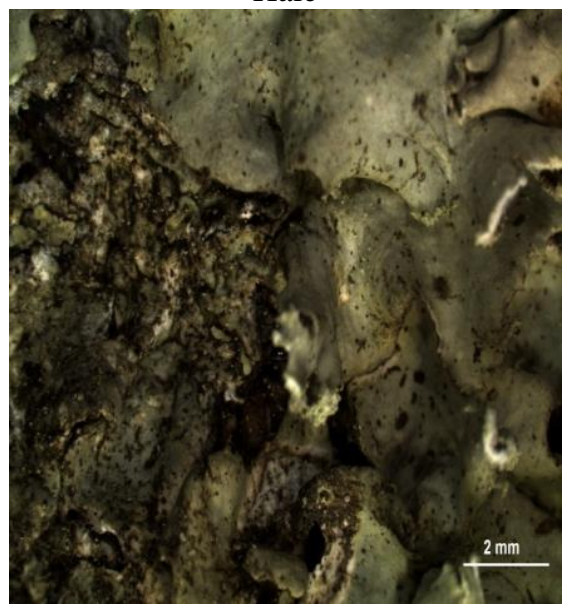

Parmotrema praesorediosum (Nyl.)

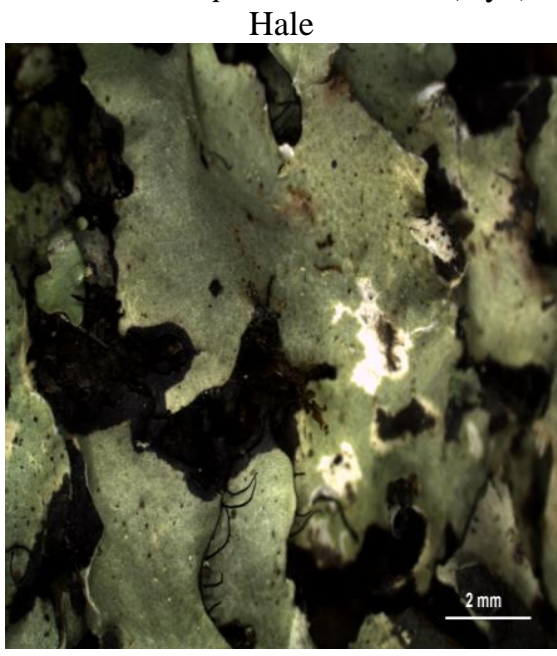

Parmotrema reticulatum (Taylor) M. Choisy 


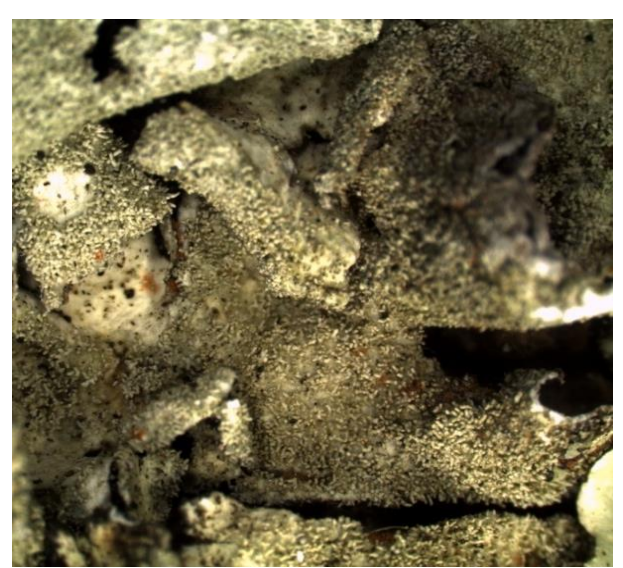

Parmotrema tinctorum (Despr. ex Nyl.)

Hale

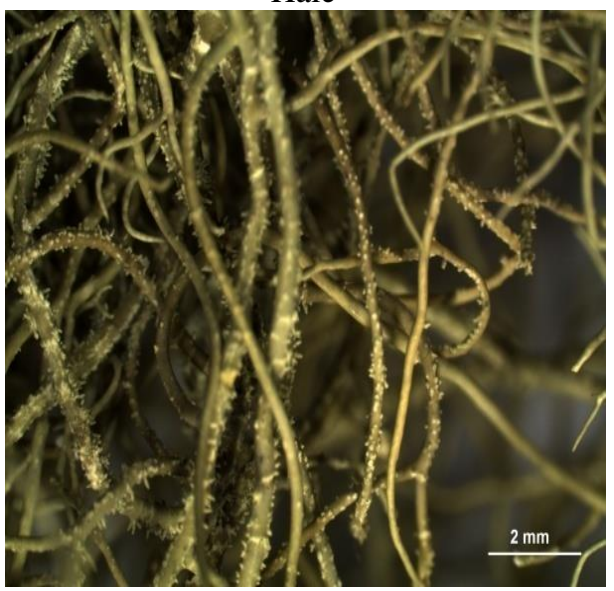

Usnea baileyi (Stirt.) Zahlbr.

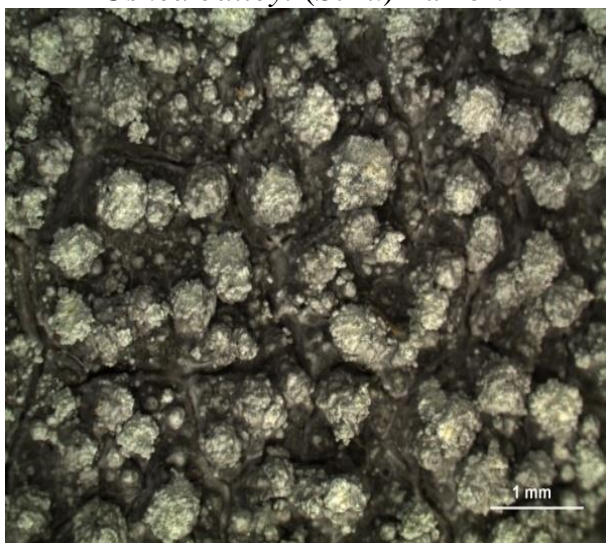

Pertusaria leucosorodes Nyl.

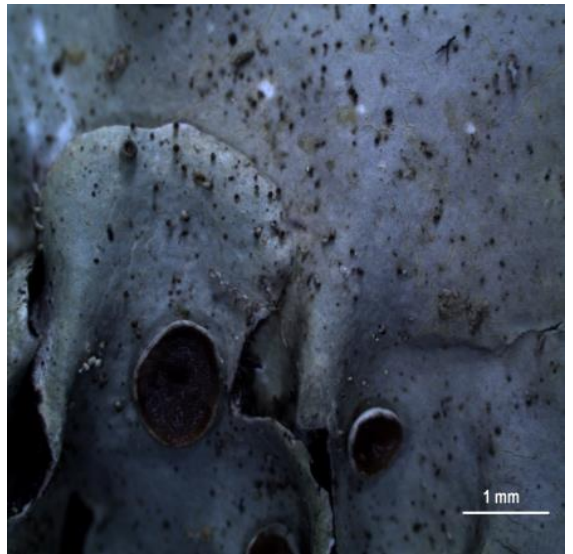

Remototrachyna rhabdiformis (Kurok.) Divakar \& A. Crespo

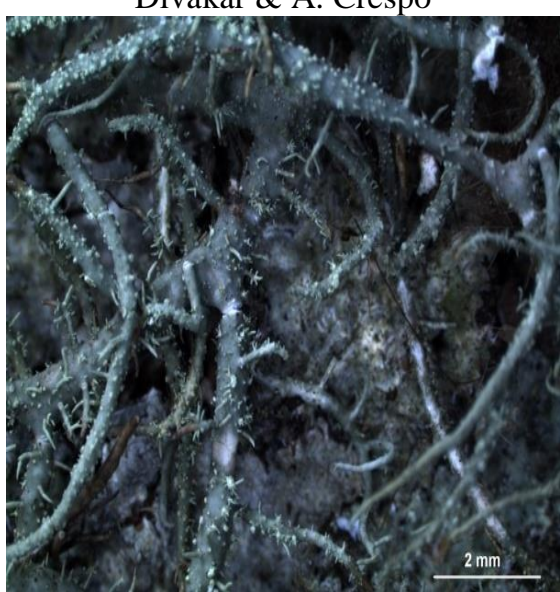

Usnea eumitrioides Motyka

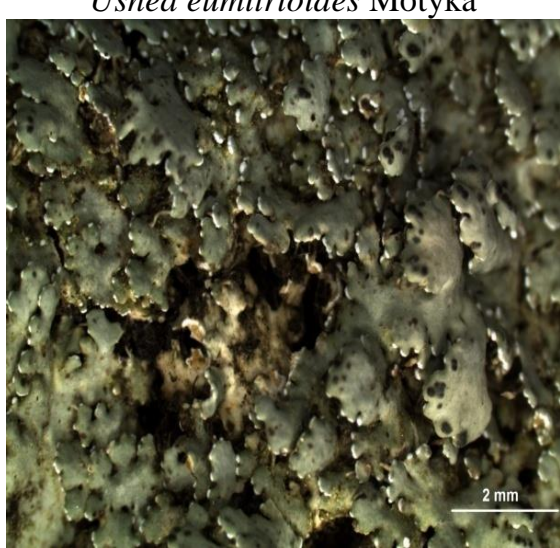

Heterodermia albidiflava (Kurok.)

D.D. Awasthi 


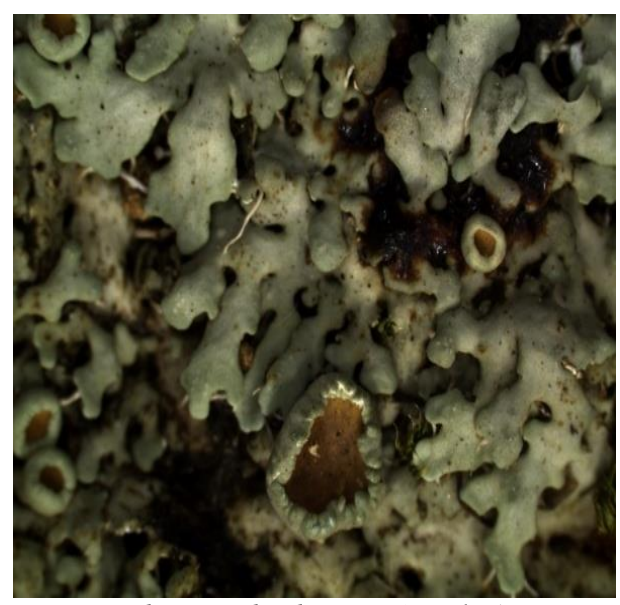

Heterodermia diademata (Taylor) D.D.

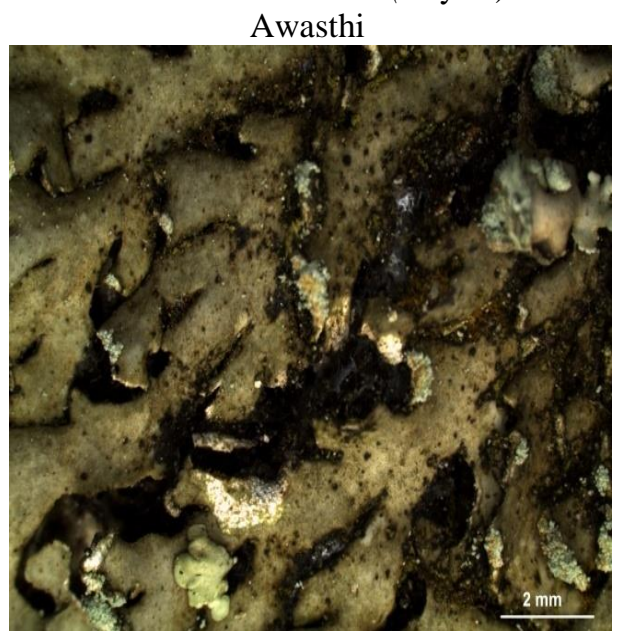

Heterodermia obscurata (Nyl.) Trevis.

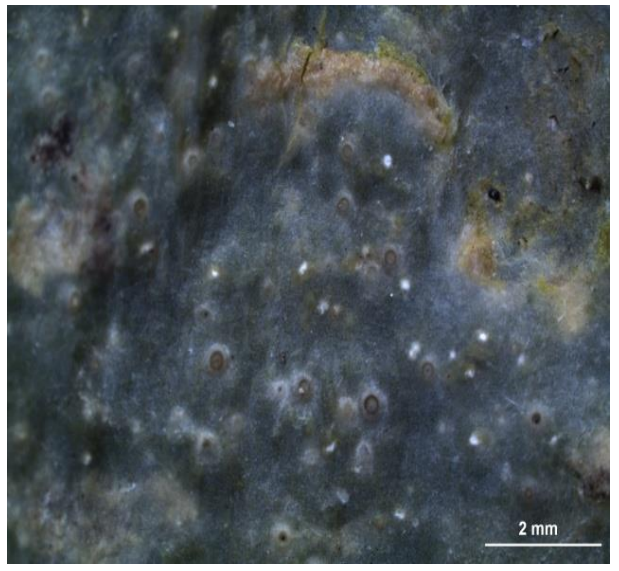

Pyrenula andina Aptroot

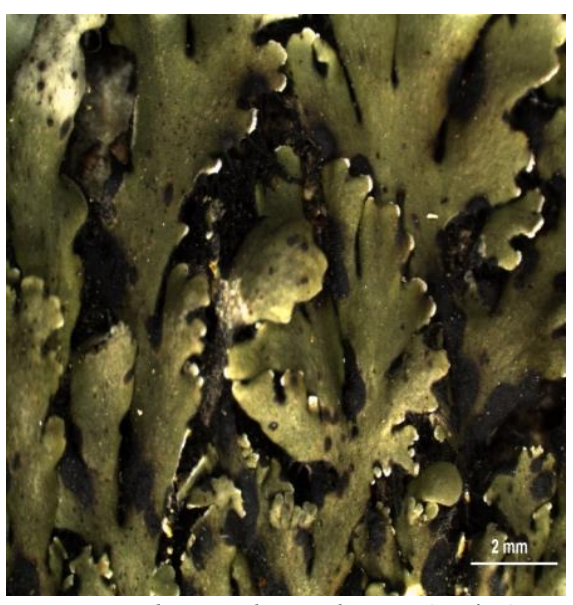

Heterodermia hypochraea (Vain.) Swinscow \& Krog

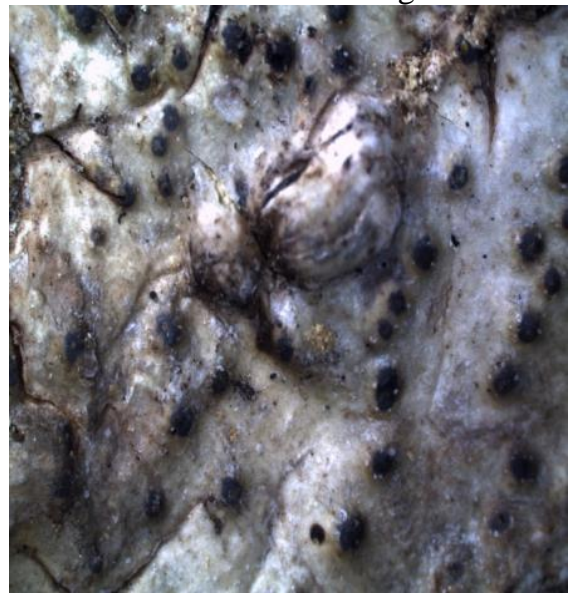

Pyrenula mastophoroides (Nyl.)

Zahlbr.

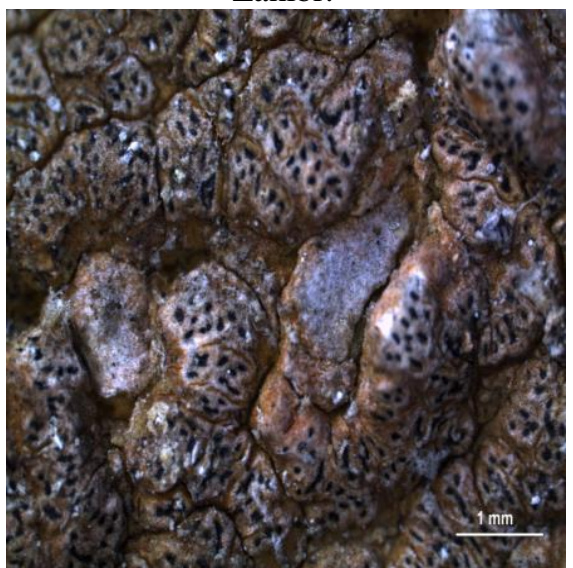

Chiodecton leptosporum Müll. Arg.

Figure 3 List of Lichens reported from Reiek hill, Mizoram and MZU campus.

With facts and findings of previous literatures, the present study also exhibited the luxuriant growth forms of both micro lichens (crustose) as well as macro lichens (foliose and fruticose) in the selected area; and it was observed during sample collection with simple floristic methods. A study conducted by Rout $e t$ al. showed the different growth forms of lichens; and they found crustose forms were dominated with 89 $\%$ of species followed by foliose with $11 \%$ of total species [39]. Similarly, Devi et al. report also highlighted the dominancy of crustose growth form with $49 \%$ over lichens distribution followed by 
foliose, dimorphic, fruticose, leprose and squamulose with 43, 4, 2, 1 and $1 \%$, respectively [25]. And with reflection of similar results as shown above, the present findings were supported by them.

The occurrence of crest forming lichen like genera Dirinaria, Diploschistes, Malmidea, Letrouitia, Pertusaria and Chiodecton together with cyanolichens genera Coccocarpia clearly indicated a moist shady habitat of the study area, which is necessary for lichens colonization. Most of the crustose genera encountered in the study area were known for their wide distribution in tropical evergreen forest of the country $[39,40]$.

The region is flourished with the distribution of genus Parmotrema viz. Parmotrema hababianum (Gyeln.) Hale, Parmotrema praesorediosum (Nyl.) Hale, Parmotrema reticulatum (Taylor) M. Choisy and Parmotrema tinctorum (Despr. ex Nyl.) Hale; which usually grow in the moist area mostly covered with trees canopy in forest getting less sunlight [41]. Additionally, the genus Heterodermia, foliose lichens is mostly grown in the tropical and subtropical region [42]. Since many previous studies had shown that the lichens are the best indicator of pollution particularly Usnea sp. which is highly sensitive to sulfur dioxide [43-45]. Similarly, the occurrence of both foliose parmelioid lichens, Bulbothrix, Remototrachyna, neighboring genus Usnea, further indicated a pollution free environmental condition in the $1^{\text {st }}$ study area i.e., Reiek in comparison with to MZU campus.

Therefore, this finding is more valuable in context to availability of lichens and their distribution in selected sites. Consequently, this study will become worthy information for the richness of lichen diversity in the biodiversity hotspot of Indo Burma region.

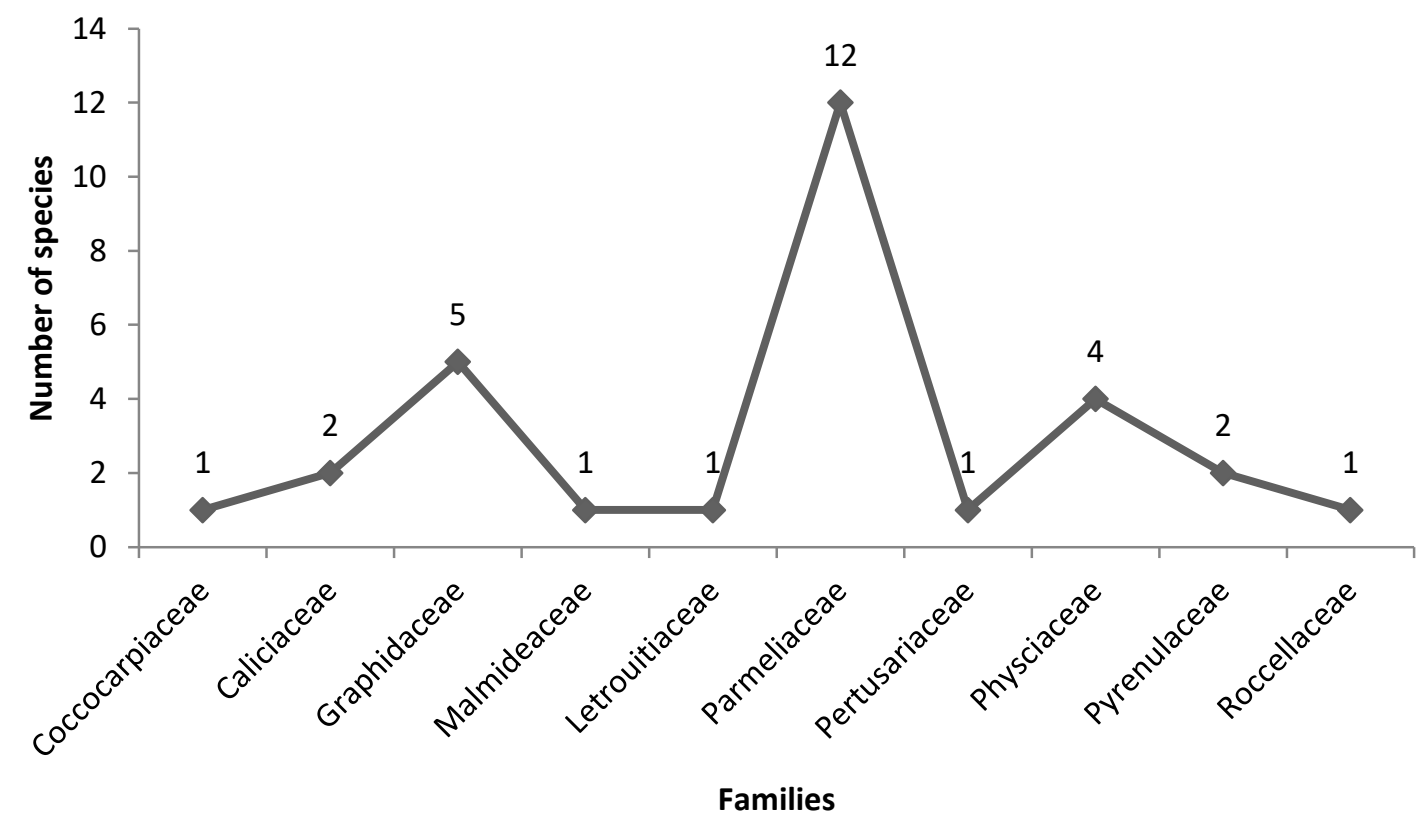

Figure 4 Dominance of the families' distribution in the 2 studies sites.

\section{Conclusions}

In the present study, the total 30 different species of lichens with addition of 9 new records for state had shown the luxuriant growth in both selected sites. The richness of lichen diversity indicates the conditions of good forest health in Mizoram. Since, jhuming and deforestation are the biggest threat for the lichens diversity even in Mizoram state, thus the study recommended for exploration of lichen species in the different parts of the state before they might get extinct. Therefore, it is a high time to generate awareness among the local people about importance of lichens with inclusion of ethnomedicine, local delicacy and pharmaceutical products. Parallely it is require minimizing the anthropogenic activities for its conservation in their natural habitat to maintain its forest health and atmosphere for longer period. Moreover, such studies may further provide a methodological approach for the documentation of lichens in the future. 


\section{Acknowledgements}

The authors are thankful to the Director, CSIR-National Botanical Research Institute, Lucknow and authorities of Reiek tourist Centre, Government of Mizoram and Department of Horticulture, Aromatic and Medicinal Plants, MZU, Aizawl, India, for providing necessary facilities during compilation of the present work.

\section{References}

[1] B Rankovic and M Kosanic. Lichens as a potential source of bioactive secondary metabolites. In: B Rakovic (Ed.). Lichen secondary metabolites. Springer, Cham, Switzerland, 2015, p. 1-26.

[2] NM Thangjam, A Kumar, AC Shukla and DK Upreti. Diversity and distribution of lichens in Murlen National Park of Mizoram, India. Environ. Ecol. 2019; 37, 664-72.

[3] B McCune. Lichen communities as indicators of forest health. Bryologist 2000; 103, 353-6.

[4] R Honegger. Lichen-forming fungi and their photobionts. In: H Deiding (Ed.). Plant relationships. Springer, Berlin, Heidelberg, Germany, 2009, p. 307-33.

[5] DJ Galloway. Biodiversity: A lichenological perspective. Biodivers. Conserv. 1992; 1, 312-23.

[6] A Aptroot. Species diversity in tropical rainforest ascomycetes: Lichenized versus non-lichenized; foliicolous versus corticolous. Abstr. Bot. 1997; 21, 37-44.

[7] R Lucking, BP Hodkinson and SD Leavitt. The 2016 classification of lichenized fungi in the Ascomycota and Basidiomycota - approaching one thousand genera. Bryologist 2017; 119, 361-417.

[8] KP Singh and GP Sinha. Indian lichens: Annotated checklist. Botanical Survey of India, Kolkata, India, 2010.

[9] KP Singh, P Sigh and GP Sinha. Lichen diversity in the Eastern Himalaya biodiversity hotspot region, India. Cryptogam Biodivers. Assess. 2018. DOI: 10.21756/cab.esp9.

[10] A Roy, SK Das, AK Tripathi, NU Singh and HK Barman. Biodiversity in North East India and their conservation. Prog. Agric. 2015; 15, 182-9.

[11] SK Tripathi, A Roy, D Kushwaha, F Lalnunmawia, Lalnundanga, H Lalnundanga, C Lalnunzira and PS Roy. Perspectives of forest biodiversity conservation in Northeast India. J. Biodivers. Biopros. Dev. 2016; 3, 157.

[12] GP Sinha and TAM Ram. Lichen diversity in Sikkim. In: ML Arrawatia and S Tambe (Eds.). Biodiversity of Sikkim: Exploring and conserving a global hotspot. Kwality Stores, Gangtok, Sikkim, India, 2011, p. 13-28.

[13] M Yilmaz, AO Turk, T Tay and M Kivanc. The antimicrobial activity of extracts of the lichen Cladonia foliacea and its (-)-usnic acid, atranorin, and fumarprotocetraric acid constituents. $Z$. Naturforsch. C 2004; 59, 249-54.

[14] M Kosanic, B Rankovic and $\mathrm{T}$ Stanojkovic. Investigation of selected Serbian lichens for antioxidant, antimicrobial and anticancer properties. J. Anim. Plant Sci. 2013; 23, 1628-33.

[15] VP Rajan, S Gunasekaran, S Ramanathan, V Murugaiyah, MW Samsudin and LB Din. Biological activities of four Parmotrema species of Malaysian origin and their chemical constituents. J. Appl. Pharm. Sci. 2016; 6, 36-43.

[16] AR Logesh, M Chinlampianga, AC Shukla and DK Upreti. Studies on lichens of Mizoram, Northeast India. Proc. Natl. Acad. Sci., India, Sect. B Biol. Sci. 2015; 87, 445-57.

[17] GB Pant. State at a glance, Mizoram. ENVIS Centre on Himalayan Ecology, Mizoram, India, 2016, p. $1-135$.

[18] HG Champion and SK Seth. A revised survey of the forest types of India. Manager of Publications, Delhi, India, 1968, p. 1-397.

[19] ST Lalzarzovi and Lalnuntluanga. Floristic composition of shrub community of Reiek Forest, Mamit District Mizoram. NeBIO 2013; 4, 55-6.

[20] ST Lalzarzovi and Lalnuntluanga. Plant community structure of tropical semi-evergreen forest of Reiek in Mamit District of Mizoram. Sci. Tech. J. 2018; 5, 58-62.

[21] Mizoram Portal, Available at: https://mizoram.gov.in/page/reiek, accessed April 2020.

[22] H Lalrinawmi, J Zothanzama, BW Held, JMC Vabeikhokhei, Zohmangaiha and RA Blanchette. The gilled mushroom Amanita spissacea (Amanitaceae): A new report for India. J. Threat. Taxa 2018; 10, 12413-7.

[23] Shodhganga, Available at: https://shodhganga.inflibnet.ac.in/bitstream/10603/1207/11/11_chapter \%203.pdf, accessed April 2020. 
[24] S Nayaka. Methods and techniques in collection, preservation and identification of lichens. In: TS Rana (Ed.). Plant toxonomy and biosystematics: Classical and modern methods. New India Publishing Agency, New Delhi, India, 2014, p. 101-5.

[25] RKS Devi, J Rout, DK Upreti, S Nayaka and A Pinokiyo. New records of lichens from Manipur State, North-eastern India. Mycosphere 2015; 6, 796-813.

[26] BJ Coppins. A key to the microlichens of India, Nepal and Sri Lanka. Lichenologist 1993; 25, 1014.

[27] P Wolseley. A compendium of the macrolichens from India, Nepal and Sri Lanka. Lichenologist 2008; 40, 267-8.

[28] S Nayaka. 2004, Revisionary studies on lichen genus Lecanora sensulato in India. Ph. D. Thesis. Dr. RML Avadh University Faizabad, Faizabad, India.

[29] PK Divakar and DK Upreti. Parmelioid lichens in India: A revisionary study. Bishen Singh Mahendra Pal Singh, Dehradun, Uttarakhand, India, 2005.

[30] P Shukla, DK Upreti and LM Tewari. Lichen genus Usnea (Parmeliaceae, Ascomycota) in Uttarakhand, India. Curr. Res. Environ. Appl. Mycol. 2014; 4, 188-201.

[31] CF Culberson and HD Kristinsson. A standardized method for the identification of lichen products. J. Chromatogr. 1970; 46, 85-93.

[32] F Schumm. Atlas of images of thin layer chromatograms of lichen substances. Books on Demand, Norderstedt, Germany, 2015, p. 1-6.

[33] R Daimari, N Hazarika, RR Hoque, S Nayaka and DK Upreti. New records of epiphytic lichens from three districts of Assam, India. Indian For. 2014; 140, 807-11.

[34] R Gogoi, S Joseph, S Nayaka and F Yasmin. Additions to the lichen biota of Assam State, India. $J$. Threat. Taxa 2019; 11, 13765-81.

[35] R Debnath, R Khare, L Gogoi, DK Upreti and J Rout. New additions of macrolichens to the lichen flora of Arunachal Pradesh, India in Eastern Himalaya. Stud. Fungi 2018; 3, 100-14.

[36] P Singh and KP Singh. New distribution records of lichens for the state of Meghalaya, North-East India. Indian J. For. 2016; 39, 245-54.

[37] M Chinlampianga, AR Logesh, U Dubey, AC Shukla and DK Upreti. Preliminary studies on lichen flora of Mizoram, North East India. Sci. Tech. J. 2013; 1, 22-5.

[38] NM Thangjam, A Kumar, KS Kumar, AC Shukla and DK Upreti. Exploration of lichens diversity from Mizoram with addition of Pyrenula dissimulans (Pyrenulaceae) a new record to India. Asian J. Conserv. Biol. 2020; 9, 98-106.

[39] J Rout, P Das and DK Upreti. Epiphytic lichen diversity in a reserve forest in southern Assam, northeast India. Trop. Ecol. 2010; 51, 281-8.

[40] A Pinokiyo, KP Singh and JS Singh. Diversity and distribution of lichens in relation to altitude within a protected biodiversity hot spot, north-east India. Lichenologist 2008; 40, 47-62.

[41] AK Dey, GK Mishra, J Rout and DK Upreti. An enumeration of epiphytic lichens from Hojai subdivision of Nagaon district, Assam, India. Int. J. Adv. Res. Biol. Sci. 2015; 2, 111-5.

[42] R Moberg. The lichen genus Heterodermia (Physciaceae) in South America: A contribution including five new species. Nord. J. Bot. 2011; 29, 129-47.

[43] DK Upreti, R Bajpai and S Nayaka. Lichenology: Current research in India. In: B Bahadur, MV Rajam, L Sahijram and K Krishnamurthy (Eds.). Plant biology and biotechnology. Springer, New Delhi, India, 2015, p. 263-80.

[44] S Gupta, R Khare, O Bajpai, H Rai, DK Upreti, RK Gupta and PK Sharma. Lichen as bioindicator for monitoring environmental status in Western Himalaya, India. Int. J. Environ. 2016; 5, 1-15.

[45] R Bajpai, S Mishra, S Dwivedi and DK Upreti. Change in atmospheric deposition during last half century and its impact on lichen community structure in Eastern Himalaya. Sci. Rep. 2016; 6, 30838. 